Research, part of a Special Feature on Toward More Resilient Flood Risk Governance

\title{
Solidarity in water management
}

\author{
$\underline{\text { Andrea Keessen }}^{1}, \underline{\text { Martinus J. Vink }}^{2,3}$, Mark Wiering $^{4}$, Daan Boezeman $^{4}$, Wouter Ernst $^{5}$, $\underline{\text { Heleen Mees }}^{6}, \underline{\text { Saskia Van Broekhoven }}^{7}$ \\ and Marjolein C. J. Van Eerd ${ }^{4}$
}

\begin{abstract}
Adaptation to climate change can be an inclusive and collective, rather than an individual effort. The choice for collective arrangements is tied to a call for solidarity. We distinguish between one-sided (assisting community members in need) and two-sided solidarity (furthering a common interest) and between voluntary and compulsory solidarity. We assess the strength of solidarity as a basis for adaptation measures in six Dutch water management case studies. Traditionally, Dutch water management is characterized by compulsory two-sided solidarity at the water board level. Since the French times, the state is involved through compulsory national solidarity contributions to avoid societal disruption by major floods. In so far as this furthers a common interest, the contributions qualify as two-sided solidarity, but if it is considered assistance to flood-prone areas, they also qualify as one-sided solidarity. Although the Delta Programme explicitly continues on this path, our case studies show that solidarity continues to play an important role in Dutch water management in the process of adapting to a changing climate, but that an undifferentiated call for solidarity will likely result in debates over who should pay what and why. Such discussions can lead to cancellation or postponement of adaptation measures, which are not considered to be in the common interest or result in an increased reliance on local solidarity.
\end{abstract}

Key Words: adaptation; climate change; collective action; governance; solidarity; water management

\section{INTRODUCTION}

Climate change will not affect all parts of society equally. Some areas are more vulnerable and some groups will suffer more strongly from climate change than others. Coastal areas, areas below sea level, and flood plains are more vulnerable to flood risks, and education, income, gender, age, and source of livelihood strongly influence people's vulnerability and adaptive capacity (cf. Adger 2003). Different normative values and cultural traditions give rise to different governance arrangements to cope with these risks. This means that there is not one single approach to decide what constitutes effective adaptation (Termeer et al. 2011, Keessen et al. 2013). Similarly, various approaches exist to bear or share the burden of adaptation (Farber 2007).

Sometimes adaptation can be carried out more effectively and efficiently through collective efforts than individually. This contradicts the idea that adaptation should be left to individuals because the gains are for those who adapt (McNall 2011). However, building or reinforcing dikes around densely populated areas to protect them from flooding is both cheaper and more inclusive than taking individual flood-protection measures, provided that there is a strong governance arrangement to implement it. In water management, man-made borders can make collaboration and collective systems rather difficult. This is particularly visible in transboundary water management, in which state sovereignty, national interests, upstream-downstream complexities, and discrepancies between policy arrangements on both sides of the border continue to hinder a more collective approach to transboundary water management (Van Eerd et al. 2015a).

Adaptation as an inclusive and collective effort, rather than an individual one, is related to the principle of solidarity. In essence, the principle of solidarity means that one acts to support members of a particular community to which one believes to belong
(Bayertz 1999). This principle was already present in a family context in Roman times. Over time it has acquired meaning beyond family ties in support of larger communities or even society as a whole (Komter 2005). Solidarity can also become compulsory. The best-known example is the welfare state, in which solidarity serves to legitimize the redistribution of financial resources by the state. Other examples are in the fields of education and healthcare, in countries in which these services have not been privatized.

This contribution investigates the role that solidarity plays in strategies for adaptation in a broad range of issues in the interplay of climate and water in the Netherlands. In many countries, the prospect of climate change has led to government plans for adaptation measures (Biesbroek et al. 2010, Berrang-Ford et al. 2011) and to changes in governance arrangements (Gasper et al. 2011, Van Buuren et al. 2014, Mees 2016). The extent to which societies expect the state to coordinate these plans and concerted action to implement them differs across countries, and it appears to be subject to change as a result of a changing climate (Adger et al. 2013, Vink et al. 2014). We address the policy debates that shape the inclusiveness of climate adaptation strategies in traditional collective governance arrangements for Dutch water management, focussing on the function and meaning of solidarity. We aim to answer the following research questions: are there any signs that the proposed measures to adapt to climate change put pressure on existing governance arrangements, and what does this mean for the role of solidarity in the various arrangements? To put it more dramatically: is solidarity-based water management still tenable in times of climate change?

We will answer these questions on the basis of a series of water management cases in the Netherlands. We have selected this country for three reasons. First, the Netherlands is vulnerable to climate change. According to the 2014 report by the Royal

${ }^{1}$ Utrecht Centre for Water Oceans and Sustainability Law, Utrecht University, ${ }^{2}$ Public Administration and Policy group, Wageningen University, ${ }^{3}$ PBL Netherlands Environmental Assessment Agency, ${ }^{4}$ Institute for Management Research, Radboud University, ${ }^{5}$ Utrecht Centre for Water, Oceans and Sustainability Law, Utrecht University, ${ }^{6}$ Copernicus Institute of Sustainable Development, Utrecht University, ${ }^{7}$ Department of Public Administration, Erasmus University 
Netherlands Meteorological Institute (KNMI 2014), Dutch winters will be less cold and wetter, whereas summers will be warmer and either drier or wetter. Extreme weather, such as hail, storms, and heat waves are expected to occur more frequently. Coupled with sea-level rise and land subsidence, this means that flood risks will increase from the North Sea, the large rivers, and from precipitation. Vulnerability further increases because of the continuous development of housing and business areas in lowlying regions. Second, the Netherlands has a strong adaptive capacity in view of its long tradition in water management (Van Koningsveld et al. 2008), its high GDP, its abundant freshwater resources, and a relatively well-defined strategy to respond to climate-change challenges. Third, solidarity was explicitly mentioned as a policy principle in the 2008 Delta Committee report, which set the Dutch adaptation agenda, and its successor the Delta Programme (Vink et al. 2013, Warner et al. 2015). The 2008 Delta report states:

Water safety is of importance for the whole of the Netherlands: a catastrophic dike breach would have disruptive consequences for the entire country. Water safety is a collective, national responsibility. This was historically the case and will always stay this way. This is a government guarantee. Based on this collective responsibility we apply the principle of solidarity: all inhabitants, no matter where they live, have an interest in water safety and will contribute financially (...).

(Delta Commissie 2008:41; our translation from Dutch).

The Delta Committee thus underlined that climate-change adaptation is a collective effort, and solidarity is given explicit emphasis. We will discuss the issue of (national) solidarity in the light of developments on different levels of governance: the supranational, the subnational, and the local level.

\section{CONCEPTUALIZING SOLIDARITY}

There is a lack of agreement as to the meaning of solidarity. Having its roots in Roman law, the term is widely used, but difficult to define (Bayertz 1999, Derpmann 2009). It refers to the unlimited liability of each individual member in a family or other community to pay common debts (Bayertz 1999). In essence, solidarity has remained the same since Roman times. A defining characteristic of a solidaristic act is that there is no equivalence between what one contributes to others or the group as a whole and what one gets in return (De Beer and Koster 2009). And as the strongest shoulders bear the heaviest burdens, solidarity reduces the gap between the fortunate and the unfortunate (De Beer and Koster 2009).

According to Bayertz (1999), solidarity consists of three key elements. First of all, solidarity takes place within a community. One does not show solidarity with everyone else, but only with the other members of the community to which one believes one' self to belong. The second element is that it is felt as an obligation to assist, which is morally commendable but not binding. The third element is that solidary action serves to promote a common good or interest. There is latent reciprocity in solidary relationships. However, solidarity can manifest itself in various forms. To capture these distinctions, we propose a simple two-bytwo matrix (Table 1) to operationalize solidarity.
Table 1. Ideal types of solidarity.

\begin{tabular}{|c|c|c|}
\hline Solidarity & Voluntary & Compulsory \\
\hline $\begin{array}{l}\text { One-sided } \\
\text { solidarity }\end{array}$ & $\begin{array}{l}\text { Moral obligation to } \\
\text { assist community } \\
\text { members in need }\end{array}$ & $\begin{array}{l}\text { Legal obligation to pay } \\
\text { taxes to fund state } \\
\text { assistance to other } \\
\text { inhabitants entitled to } \\
\text { assistance }\end{array}$ \\
\hline $\begin{array}{l}\text { Two-sided } \\
\text { solidarity }\end{array}$ & $\begin{array}{l}\text { Reciprocal moral } \\
\text { obligation to further a } \\
\text { common interest }\end{array}$ & $\begin{array}{l}\text { Legal obligation to pay } \\
\text { taxes to fund state } \\
\text { measures to further a } \\
\text { common interest }\end{array}$ \\
\hline
\end{tabular}

First, we distinguish solidarity to assist community members in need, so-called one-sided solidarity, and solidarity to promote a common interest, so-called two-sided solidarity (De Beer and Koster 2009). In the case of one-sided solidarity, the assistance is given to a community member without expecting anything in return. An example is the practice of giving alms to beggars. By contrast, two-sided solidarity operates in two directions. It is strongly based on mutual interdependence, limited information on individual risks, and the expectation that one's contribution is balanced by an equivalent (future) contribution by someone else. One expects on balance to benefit just as much from others as they themselves are contributing (De Beer and Koster 2009). A good example is fire and theft insurance, through which people cover themselves against the hardship of these calamities by pooling their risks. It is important to note here that in practice, the distinction between one-sided and two-sided solidarity is often unclear (De Beer and Koster 2009) and a solidaristic act can therefore be a hybrid construction of one-sided and two-sided solidarity.

Second, in line with De Beer and Koster (2009) and Bayertz (1999), we distinguish between voluntary and compulsory solidarity because voluntary solidarity is organized through private initiatives, whereas compulsory solidarity depends on state intervention. It is not just the contrast between the private and public domain that makes compulsory solidarity different from voluntary solidarity. The compulsory character also changes the nature of the "gift," because the assistance becomes an enforceable right for those who are entitled to it on the basis of formal criteria. This perspective eventually reduces the reciprocal nature of solidarity (Bayerz 1999). Compulsory systems of solidarity can therefore evolve from two-sided to one-sided (entitlements), although a moral appeal justified its original establishment (Steinvorth 1999).

Solidarity is not a given but can induce discussions regarding belonging to the group and who should get what and why. Such discussions are as old as the original context of solidarity: the family. Brothers and sisters do not share everything because they want to (voluntary solidarity), but because their parents expect them to share (moral obligation). And siblings often fuss about the fairness of the criteria for the distribution of material goods (Munoz-Dardé 1999). Making an act of solidarity a compulsory one does not make it immune to such discussions. It is also important to realize that people's attitudes may differ. Some are 
cosmopolitans, who consider everyone to be part of their community (Derpmann 2009), others are selectivists, whose solidarity is conditional, and such attitudes may change over time (Van Oorschot 2000).

An important condition for the willingness to offer one-sided solidarity is the locus of individual or group responsibility, which refers to the extent to which problems are beyond the control of those in need. The weaker the control, the less strongly people can be held responsible, and the more support they are considered to deserve (Cook 1979, De Swaan 1988, Van Oorschot 2000). Other factors affecting one-sided solidarity are the identity or proximity of those needing support, perceived abuse and freerider behavior (Van Oorschot 2000), and a demand for freedom of choice (De Beer and Koster 2009). Two-sided solidarity can be affected by a lack of community spirit, perceived abuse, and freerider behavior as well. If benefits are seen to help some groups more than other groups, which can be identified beforehand, twosided solidarity becomes one-sided solidarity (De Beer and Koster 2009). The above characteristics are important in the study of changes regarding the principle of solidarity in the face of climate change. Is the current system of water management, which is based on solidarity, still widely accepted? What about discrepancies between regional or local costs and benefits on the one hand, and national costs and benefits on the other hand?

\section{METHODS}

To gain in-depth understanding of the role of solidarity in Dutch water management under adaptation stress, we decided on a nested case-study approach, selecting six subcases with a maximum variety of water management issues (Flyvbjerg 2006), geographically spread over the Netherlands (see Fig. 1). Our encompassing case is Dutch water management in view of a changing climate, and its recent manifestation in the national Delta Programme. The six subcases deal with flood risks and freshwater supply at the international, regional, and local level. We believe that this broad view offers a comprehensive approach to climate-change effects, although we are fully aware that this article only covers the issue of water management.

The cases are based on a four-year research program on knowledge for climate. One of the core work packages of this program was named "normative principles" and analyzed the role of certain governance-based, environmental, and legal principles in Dutch climate adaptation. The individual cases were part of dissertation projects and the information was collected and discussed by the team of researchers in several workshops on solidarity. To determine the role of solidarity, we will describe the proposed or actual measure and analyze the decision-making process, for each case, to uncover to what extent solidarity was discussed.

Because the people involved in the case studies did not necessarily explicitly talk about solidarity, the process labels were interpreted by different researchers to determine whether and to what extent these people's experience fits our definition of one-sided or twosided solidarity and to what extent solidarity appears to be under pressure. Our research material consisted of three main sources. First, we conducted semistructured interviews with experts, policy makers, and stakeholders. Then, we analyzed policy documents, studies, memos, and minutes. Third, we performed (participant) observations of project meetings. Comprehensive methodological justifications can be found in the respective research publications on the case studies (Mees et al. 2014, Boezeman 2015, Keessen and Ernst 2015, Van Eerd et al. 2015a, Vink 2015).

Fig. 1. The location of the six adaptation strategies.

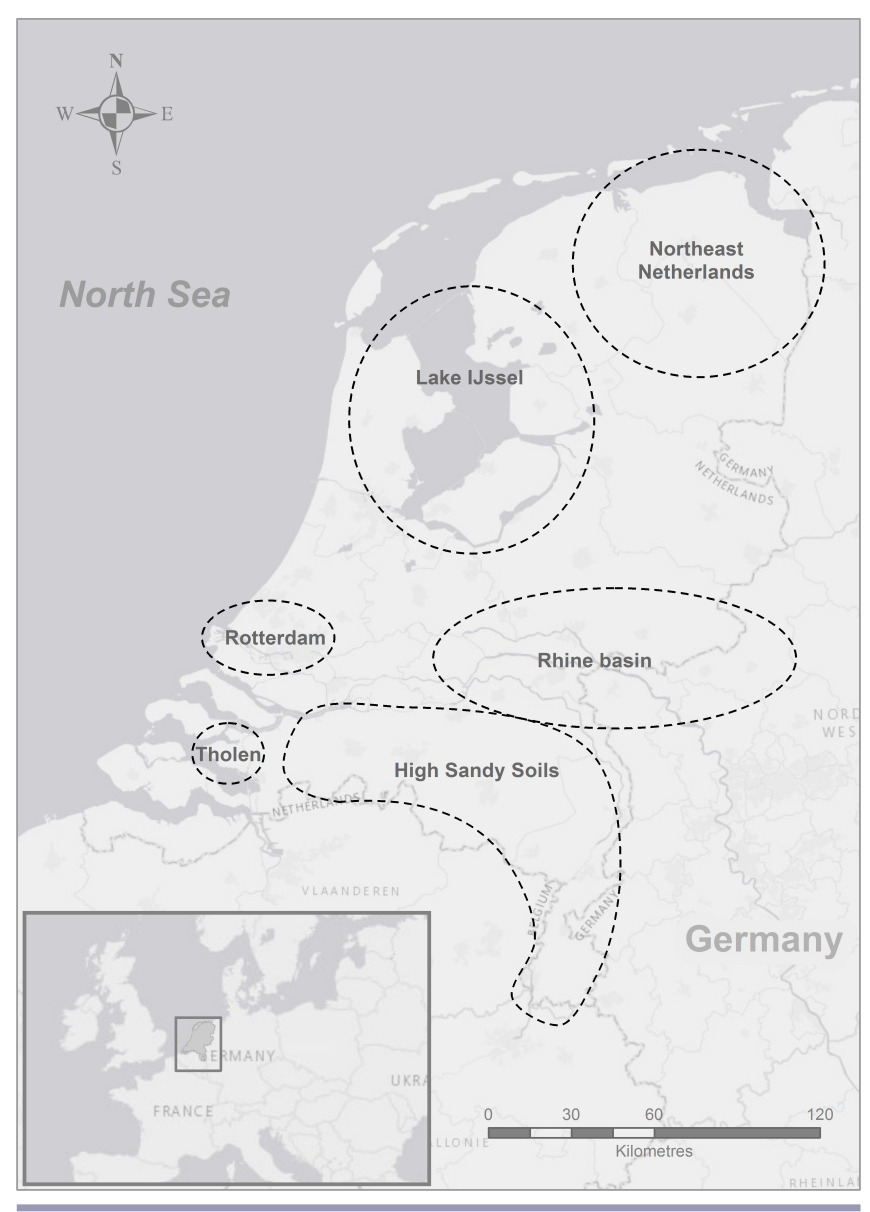

\section{RESULTS}

Solidarity and adaptation at the national level

The origins of the two-sided nature of solidarity in Dutch water management are more than 1000 years old. Because the first inhabitants of flood-prone areas lived on self-made mounts, in the early Middle Ages, water management was already a collective task. Communities established water boards to create polders and build and maintain dikes. During the French rule of the Netherlands (1795-1813), water management was partly centralized and became a public responsibility. This resulted in the approximately 2000 water boards being transformed into government authorities and in the establishment of a national water agency to manage the main rivers (Prak and Zanden 2013, Warner et al. 2015). The introduction of a national water agency made it possible to promote interests beyond the water-board level within the larger community of the Netherlands, thus creating a system of national compulsory solidarity.

The traditional governance structure of the water boards is based on the trio "stake, say, pay." The compulsory two-sided solidarity 
origins are still reflected in the water-management taxes. The water boards' work is funded by water taxes on the basis of the economic value of all properties in their area. The increase in the responsibilities of water boards resulted in mergers, now leaving only 23 water boards, and also resulted in stronger risks of conflicts regarding what the common interest requires be done. Moreover, tax reforms resulted in households paying a disproportionately large contribution to water management compared to agriculture and industry (Dekker and Havekes 2013). Agriculture and industry therefore benefit from the onesided solidarity from households under the current taxation regime.

Fear regarding the impact of climate change has led to changes in water management. In response to scientific alarm, the Dutch Senate passed a resolution in 2005 to establish a political advisory committee tasked to review Dutch flood safety, in view of the country's increased population, wealth, and the changing climate. This Delta Committee drafted an advisory report based on rather extreme climate scenarios, pointing out an urgent need to make the Netherlands climate proof (Delta Commissie 2008). By emphasizing the exogenous nature of climate change, which was claimed to threaten the nation's prosperity as a whole, the framing of the advisory report had a national scope (Boezeman et al. 2013, Vink et al. 2013).

Correspondingly, solutions were sought in institutional reform toward further centralization and large infrastructural investments to be paid with taxpayers' money based on solidarity (Vink et al. 2013). Although expensive, and constitutionally at odds with the Dutch corporatist tradition of decision making, the proposed reforms were accepted by government and parliament without substantial opposition (Vink et al. 2015). In 2010, the Dutch government responded to the committee's recommendation by establishing the Delta Programme, the Delta Commissioner, and the Delta Fund, which are all legally rooted in the new Delta Law (incorporated in the Water Act 2009; NMTPWWM 2010) and operate under the Minister of Infrastructure and Environment.

Interestingly, the Delta Programme is explicitly based on solidarity in the context of flood safety because solidarity contributions from the Delta Fund are justified by fear of societal disruption in case of a flood event (Delta Programme 2013, 2014). Disruption on a national scale, in case of an event, appears to be the main justification for generous solidary contributions from the state to a region (Delta Commissie 2008). The criterion of disruption on a national scale implies that there is a common interest, promoted by two-sided solidarity. However, it is obvious that solidary contributions for flood safety will be concentrated in regions with flood-prone areas. For higher areas, this therefore constitutes a compulsory one-sided solidarity.

One-sided solidarity in flood-risk management is also present at the water-board level. When the state and the water boards agreed in 2011 that the state would reduce its contribution to $50 \%$ for measures to improve primary flood defences, the water boards filled the gap. They pay $40 \%$ through a solidary contribution by all Water Boards, which leaves $10 \%$ as an individual contribution of the water board concerned (Helpdesk Water 2011). Their voluntary solidarity was rendered compulsory by codification in the Water Act 2009 (Article 7.24). The water boards thus counteracted the step toward stronger reliance on compulsory two-sided solidarity. Their solidarity has a mixed character. It is two-sided for the water boards with flood-prone areas, but onesided for water boards without any flood-prone areas. It therefore reinforced the compulsory one-sided solidarity element in flood safety. The policy debates in the case studies illustrate the role solidarity plays at various levels and in different circumstances.

\section{Six examples of solidarity at the international, regional, and local levels}

\section{The international level}

The Rhine basin: solidarity or no harm

The Rhine basin is a community of riparian countries that cooperate on a multilateral basis in the International Commission for the Protection of the Rhine (ICPR). Voluntary, two-sided solidarity could be regarded as the principle triggering collaboration in the Rhine basin. A good example is the Rhine Action Plan on Floods (ICPR 1998) in which all riparian countries cooperated to decrease the flood risks within the entire basin. Indeed, international collaboration in the Rhine catchment is often identified by scholars as one of the most successful examples of cross-border cooperation (e.g., Bernauer and Moser 1996). Managing flood risks remains one of the main challenges for the Rhine basin (Kabat and Van Schaik 2003, Te Linde 2011).

Interestingly, the European Floods Directive 2007/60 EC (hereafter, FD) explicitly mentions solidarity twice. According to the FD, solidarity means that (1) member states should not take any measures that increase flood risks in other states, unless these actions are coordinated, and that (2) members should seek fair sharing of responsibilities (European Parliament and Council 2007). The directive does not contain any provisions on international assistance (Van Eerd et al. 2015a, b). Interestingly, all actors in the Rhine basin interpret the solidarity principle differently. For example, Germany took the position that measures should be in the interest of all actors affected in the basin, also considering positive effects. By contrast, the Netherlands invokes solidarity to remind upstream countries that they should not pass flood risks to downstream countries (Van Eerd et al. 2015a).

International solidarity under the FD can be shaped and regarded as two-sided solidarity. The Dutch delegation explicitly referred to solidarity to overcome collaboration difficulties in the ICPR (Van Eerd et al. 2015a). The institutionalization of solidarity in the FD thus helped raise the awareness in the basin of the need for solidarity. Nevertheless, it is just one aspect within the complexity of transboundary flood risk management in which factors, such as state sovereignty, national self-interests, and upstream-downstream complexities, continue to hamper taking a collective approach (Van Eerd et al. 2015a). An intriguing example in this regard is that member states' climate adaptation plans continue to focus on their national situation. The successive Dutch Delta Programmes (key aspect of Dutch adaptation policies) have maintained their purely national focus. They do not consider possibilities for cross-border cooperation or identify any impacts of the program for upstream regions. This means that international cooperation is only slowly progressing from avoiding harm, i.e., flood risks, toward taking two-sided solidary action to decrease flood risks in the basin as a whole. 


\section{The regional level}

Solidarity in northeast Netherlands

In 1998, northeast Netherlands was shocked by unexpectedly serious floods. Evacuations and intentional inundations prompted the water boards of Aa en Hunze and Noorderzijlvest, and the provinces of Groningen and Drenthe to jointly initiate risk-management projects to strengthen water safety in the region. The catchment areas receive drainage water from the polders and discharge it into the Wadden Sea, Ems, or Dollard. Because of climatic changes, it is believed that this process will become increasingly difficult. The KNMI (2014) climate scenarios projected an increase in winter precipitation by $3 \%$ to $17 \%$ and a sea-level rise of between 15 and $40 \mathrm{~cm}$ in 2050, because soil, currently already below sea level, is subsiding. The region is particularly vulnerable because of storms and substantial precipitation, making water discharge (temporarily) impossible (Van den Hurk et al. 2015). After the 1998 events, the provinces set an equal safety norm of 1 flood in 100 years for the area, but the Dry Feet 2050 (2011-2014) project proposed to set new flood norms and policies in the face of provincial ambitions to increase flood safety, in view of climatic change and ongoing soil subsidence due to gas mining (Boezeman et al. 2014).

Two important issues regarding solidarity emerged during the norm-setting process. The first relates to the differentiation in safety levels because of a new norm-setting method. Each polder is categorized based on the calculated economic damage in case of an inundation. The aggregated potential damage determines the safety level in the polder. Grasslands may flood once every 10 years, urban or high-level industrial areas once every 300 or 1000 years. Previously, the differences were not that large because the province had set a minimum safety level for each member of the community. Nevertheless, the province and water board now differentiate protection levels among the polders, despite the undifferentiated water management taxes. This approach results in the accrual of benefits among the polders with the highest amount of vulnerable assets, which is justified by the argument that granting a higher, yet for every inhabitant equal, safety level would be very costly: an "equal-rights approach is not possible because it would be financially unaffordable" (interview, Groningen 7 March 2013). Thus, solidarity remained compulsory, but lost part of its two-sided character. The discussion on the fairness of sharing equal costs while obtaining unequal benefits is expected to return in the aftermath of a flood event.

Second, a discussion emerged on who should finance measures to prevent inundation of installations of the national gas company (Dry Feet 2050 project meeting, May 2014). Because inundation damage to such installations may result in the gas supply to a region as big as northwestern Europe being cut off, these locations were awarded the highest levels of protection. A discussion ensued about whether it would be fair if the local community, i.e., the inhabitants of the entire catchment area, were to pay for the extra protection of the gas location, while the state, and hence the Dutch community as a whole, reaps the annual benefits of several billions of Euros; a sensitive issue in the region. On top of this, the national gas company had constructed a new nitrogen plant in the floodprone Tussenklappen polder, effectively increasing potential damage. The advice of the water board had been overruled by the Ministry of Economic Affairs on the grounds that this was in the national interest. In this case, it did not (yet) happen, but the Delta Programme includes examples of voluntary private payments, which are used to increase the quality of flood-defence measures (Delta Programme 2014). Further discussion is expected to develop on the question of whether economically valuable or industrial locations must pay more for additional safety measures instead of relying on (one-sided) solidarity.

\section{A solidarity failure in the Lake IJssel region}

Lake IJssel is the largest freshwater lake in the Netherlands. The Delta (sub)program DPIJ developed strategies to raise the lake's water level by 1.5 metres to increase water storage for dry periods, especially for agricultural and water management purposes in the west of the country, and also to fight against salt water intrusion from a rising sea. However, rising water levels would potentially inundate harbor areas and nature reserves and threaten touristic waterfronts around the lake. Because the Lake IJssel region would bear the costs without having any benefits from the plans, it was not surprising that the plans sparked opposition among the regional and local governments and stakeholders in this area. (Delta Programme 2011, Vink et al. 2015).

The DPIJ attempted to accommodate the initial opposition by initiating a semiopen, ad hoc consultative governance approach parallel to the different layers of constitutional decision making. Around 300 regional and local political decision makers, administrators, experts, and stakeholders were regularly invited to share ideas and formulate broad-based strategies for raising the lake's water level. The approach initially yielded enthusiasm among participants, which gradually faded. The DPIJ framed the national freshwater goal as a technical problem, implying knowledge and management as the fundamental problem, and expertise and efficiency as the solution. Formulations like "working on a water task" and "updating an outdated water management system" downplayed initial opposition.

The Delta Committee emphasized fundamental questions regarding the allocation of costs and benefits and solidarity, whereas the DPIJ either incorporated these questions in general technical frames, implying efficiency solutions, or avoided them by referring to other fora as more appropriate for debating solidarity issues. The technical framings avoided political conflict, but led to apathy among political decision makers. Accordingly, deliberations remained apolitical (Vink et al. 2013). By translating the attempt to achieve voluntary one-sided solidarity into a technical cost-benefit analysis, the issue was finally settled without political negotiation between regional and national political decision makers (Bos and Zwaneveld 2012). The analysis resulted in the 1.5-metre plan being postponed for not being cost effective. It seems that the controversial solidarity dimension of the issue was sidestepped here.

\section{High Sandy Soils (DHZ): two-sided solidarity or one-sided} solidarity

In the higher areas of the Netherlands, water-scarcity measures are necessary to adapt to climate change. Because drought was not immediately seen to meet the national disruption criterion for national solidarity through the Delta Fund, various actors decided to start their own initiatives. Water boards, the provinces of Brabant and Limburg, nature organizations, agricultural organizations, and drinking-water companies started the Delta Plan High Sandy Soils (DHZ) as a regional climate adaptation 
initiative. Since 2012, DHZ has been cooperating with the similarly organized collaborative program Fresh-Water Supply East Netherlands (ZON). Together they refer to their entire region as the high Netherlands (see Fig. 1), signalling the difference with lower areas where flood protection is a main issue in climate adaptation.

The regional DHZ ran in parallel with, and partly as a reaction to, the national Delta Programme, which has a national subprogram on freshwater supply. Over the years, a closer relationship with and participation in the Delta Programme has developed to gain support at the national level for the issues of the high sandy grounds. The actors participating in DHZ and ZON made a regional offer to the Delta Programme on freshwater in 2014. In addition to a regional program of measures, this offer involved a claim for a financial contribution from the national Delta Fund for implementation. The actors involved would contribute funds as well.

In the case of DHZ, the principle of solidarity can be identified in the discussions that arose regarding the agenda setting of the Delta Programme and the distribution of finances and resources from the national Delta Fund. The DHZ program requires a financial contribution from the national Delta Fund to address issues of drought and freshwater supply in the southeast region of the Netherlands. This is currently a claim for voluntary onesided solidarity of the Netherlands as a whole toward these regions. If the proposal of the Delta subprogram on freshwater supply to establish minimum levels of freshwater supply were adopted, this could imply the creation of a right and perhaps lead to more contributions from the state or the Delta Fund. The DHZ argues that a fair share for drought measures in higher regions should be discussed, because the share of funds going to flood protection is very large and mainly benefits the western floodprone regions, meaning that it is not two-sided but compulsory and one-sided from the perspective of the higher regions. Therefore they argue in favor of one-sided solidarity contributions for their drought management measures.

\section{The local level}

Tholen: two-sided solidarity at the local level

Tholen is a former island in the province of Zeeland, surrounded by Lake Volkerak-Zoom, the Oosterschelde estuary, and the Scheldt Rhine canal. The land is mainly used for agriculture (De Vries et al. 2009), but the supply of freshwater via precipitation and groundwater is insufficient to meet the current and anticipated agricultural demands. After the implementation of the Delta Works, the groundwater chloride levels at Tholen decreased, but remained inadequate for irrigation purposes. The Tholen branch of the farmers' association lobbied for decades on behalf of the local farmers to facilitate freshwater supply from outside the island (Keessen and Ernst 2015). Although the initial plan to improve freshwater supply to farmers was not carried out because of a lack of funding, water board Zeeuwse Eilanden decided, in 2001, to initiate a pilot project to improve irrigation on 1000 ha (Waterschap Zeeuwse Eilanden 2009). In April 2013, after a series of talks and negotiations, this pilot project led to a jointly drafted proposal from the water board and the Tholen farmers' association. The proposed structural arrangement for freshwater supply on Tholen included a payment scheme. Nearly $80 \%$ of the farmers supported the proposal (Waterschap Scheldestromen 2013a).
The water board's special tax scheme ensures that the measure is paid for by the users, defined as owners and right holders of tenure of unbuilt agricultural lands on Tholen, regardless of whether and how much water they abstract from the ditches. Taxation here is directly related to the use of facilities owned or managed by the water board, i.e., the local ditches, sluices, pumps, and other facilities (Keessen and Ernst 2015). An informal advisory council, consisting of users distributed geographically over the three tariff zones was established in May 2013 to participate in the management of the freshwater supply from the lake, most notably to advise on future investments for the improvement of the local freshwater supply (Waterschap Scheldestromen 2013b). This adaptation measure, therefore, provides an example of the continued relevance of collective action in water management. After a majority of the farmers voted in favor of the proposed arrangement, inclusion became compulsory, thus creating twosided compulsory solidarity. However, this arrangement is now threatened by natural and man-made changes. Because the lake will become brackish to improve water quality, the farmers on the island need to find new water resources and create another new arrangement.

Heijplaat (Rotterdam): one-sided solidarity and individual action Climate change also brings challenges for areas that are unembanked and in which flood safety is a private responsibility. The municipality is an important player in this regard because the water authorities are only responsible for the flood safety of people who live within their dike rings and are not responsible for unembanked areas. Hence, when the municipality of Rotterdam wanted to transform the unembanked harbor districts in the inner city into new innovative residential and working areas (http:// stadshavensrotterdam.nl/en/), it had to consider flood-safety aspects as well. The usual approach is to raise the area to avoid flooding. It is then up to the businesses and citizens to arrange for their own flood protection and cover their own damages, but in urban areas many inhabitants are unaware of these flood risks (De Boer et al. 2012). In addition, they lack a sense of urgency. Citizens are more concerned with the level of social services (school, supermarket, etc.) of their neighborhood (Mees et al. 2014).

Nevertheless, the decision-making process was quite collaborative and involved all the relevant public and private stakeholders. It resulted in a public-private partnership, a contract signed by all partners including a residents' representative, although Rotterdam's mayor and aldermen formally took the key decisions on flood-safety measures (Mees et al. 2014). As a result, part of the early-1900s village has been demolished to allow for new development, and part of the old village will remain as it is. The new part of Heijplaat will be built adaptively. Flood proofing new houses is less expensive than raising the new village and avoids ugly ground-level differences between the old and the new part. Under the municipal rules, the responsibility for this floodproofing work lies with the project developer and the future residents (Mees et al. 2014). In addition, a partial levy is planned and financed by the municipality to raise the protection level of both old and new Heijplaat to a 1 in 250 years flood probability. Nevertheless, there will be a difference in flood protection between the old ( 1 in 250 years) and the new village ( 1 in 4000 years, which corresponds with the parts of Rotterdam that are protected by dikes), because of the flood proofing of the new village (Mees et al. 2014). 
The Heijplaat case shows a form of voluntary one-sided solidarity: the municipality has taken the initiative to finance and implement the partial levy for the residents of Heijplaat, with tax money borne by all residents of Rotterdam. However, there is no form of solidarity with regard to the constructive measures. Even if the project developer implements flood-proofing measures collectively (it is more efficient to do so on a large scale during construction), the flood-proofing measures still have an individual character for the specific residents of the flood-proof houses and their legal successors (Mees et al. 2014). Another interesting point of discussion is the difference in flood protection between the old village on the one hand, and the new village and the rest of Rotterdam on the other hand. What will happen when a flood causes serious damage to the houses in the old village? Officially, they have to bear their own damage because the national government is not obliged to compensate for damage in unembanked areas. Actually, it will be a social housing corporation who will suffer most of the damage. Perhaps the municipality might have or feel a moral duty to help those in need in case of serious damage, as an expression of voluntary one-sided solidarity because these are Rotterdam citizens, and the municipality allowed the development of this unembanked area based on the then best-available data.

\section{DISCUSSION}

All case studies illustrate the important role that solidarity plays in Dutch water management due to the historical preference for collective arrangements. They also show that solidarity in water management is not immune to controversies, as was also shown in the context of the welfare state (e.g., Van Oorschot 2000, De Beer and Koster 2009, Van Houwelinge et al. 2014). The changing climate may also change the way solidarity issues are addressed. The Delta Programme justifies compulsory solidarity contributions from the Delta Fund to flood-prone regions, referring to the threat of major flood events leading to disruption on a national scale. Although the water boards in the higher regions appear to agree with this criterion, they also lobby to acquire Delta funding for water-scarcity measures, thus revealing the importance of reciprocity in solidary relationships.

Indeed, the approach to flood safety stands in stark contrast with the self-supportive financial arrangement that applies to other water tasks. Water boards can finance these tasks by raising their own taxes, which are traditionally based on two-sided compulsory solidarity in the water board's territory. An explanation for the difference between flood safety and other water tasks could be the high costs involved in improving flood defences. This seems unlikely however, because measures to improve water quality or water supply can be very expensive as well. However, for the implementation of those tasks, each water board has individual financial responsibility. Another explanation is that one-sided mandatory solidarity is justified because floods are a natural phenomenon and therefore beyond the control of those affected, but this applies to water-scarcity problems as well. The most likely explanation is the disruptive effect of major floods, which warrants one-sided solidary contributions in advance because bearing the costs of the aftermath of a flood is even more expensive.

When national solidary contributions are contested, a possible solution is to rely on solidarity at the regional level. However, solidarity can be contested at this level as well. Contested solidarity can lead to postponement and a reduction in adaptation measures, as with the Lake IJssel area, the northeastern Netherlands, and the High Sandy Soils have shown. A lack of means or options for collective solidary approaches can also lead to the reemergence of individual measures, as the Heijplaat case shows, in which flood-prone buildings supplement the safety provided by the levy. The example of Tholen suggests that a lack of national solidarity can be overcome by seeking two-sided solidarity in the region. Looking beyond the nation state for solidarity, for instance at a river-basin level, is not an option there because solidarity at that level is hardly beyond the stage of a duty to avoid harm.

Considering that the Netherlands spends billions on water management (e.g., GNMIE 2012, Dekker and Havekes 2013), it is surprising that it remains relatively quiet on the related financial arrangements and their underlying principles and consequences. This could be due to the depoliticized, expert nature of water management. There appears to be broad consensus (or rather broad acquiescence) regarding the advantages of the collective and solidary character of water management. This is visible in the Delta Programme's policy documents and in the visionary report of the Delta Committee. And as our case studies show, solidarity is firmly rooted in the various adaptation measures on the ground. However, a closer look at the various forms of solidarity shows that solidarity cannot be taken for granted. If expectations of reciprocity are not met, this suggests that increased reliance on one-sided solidarity represents an insufficient reflection of the preference for two-sided solidarity to fund water-management measures.

\section{CONCLUSIONS}

Our research questions were whether or not there are any signs that the measures proposed to adapt to climate change put the existing governance system under pressure, and what this means for the role of solidarity in various arrangements. Although not always explicitly mentioned, our case studies confirm that solidarity lies at the roots of both national and regional watermanagement adaptation strategies (cf. Wiering et al. 2015). However, discussions have revealed that solidarity can no longer be taken for granted. Undifferentiated calls for solidarity may incite discussion over who should pay how much and for what reason. The distinction between two-sided (collectively promoting a common interest) and one-sided (assisting those in need) solidarity is useful in this regard. Regional actors do not consider every adaptation measure to automatically be of common interest. If a measure is said to of the common interest, regional actors rightly expect it to promote their interests as well, instead of it being a mere request for assistance with a more onesided character.

Such a selfish attitude does not signal the end of a collective approach. On the contrary, the debate regarding the fair share of the Delta funding for water-scarcity measures is essentially about establishing reciprocity to maintain two-sided solidarity relationships. Suppressing the moral side of the debate by taking a purely technical and cost-benefit perspective, as occurred in the Lake IJssel region, does not seem to be a good answer to a solidarity crisis. Debate in itself is not a threat to solidarity, but a sign that the form of solidarity or the way it is organized needs 
to change (De Beer and Koster 2009). In a democratic society, it should be possible to have a transparent and public debate regarding what kind of adaptation measures are really necessary and to what extent those in need are able to fund adaptation measures themselves (cf. De Beer and Koster 2009). In this regard, it is also relevant which other social goals can be advanced by various adaptation measures (Farber 2007).

Our case studies show that debates regarding forms of solidarity are not a real threat to the existing governance approach, because two-sided solidarity is still firmly embedded in the system. Onesided solidary contributions only offer part of the required funding for adaptation measures. Controversies sparked some changes, although they remained under control through pragmatic solutions: e.g., reducing the requested one-sided contribution in the Lake IJssel area and increased lobbying for a fair share for drought-management measures in the High Sandy Soils case to create two-sided solidarity for adaptation measures. Interestingly, the small-scale case studies showed two inherently different responses to a solidarity crisis: strengthening two-sided solidarity at the local level in Tholen and combining a one-sided solidarity contribution with individual adaptation measures in Rotterdam. These examples show that rejected (one-sided) solidarity does not have to lead to postponed or reduced adaptation measures. It can also result in a revival of historical governance modes, when two-sided solidarity was the norm and water management was organized on a much smaller scale, involving citizens more directly.

Responses to this article can be read online at: http://www.ecologyandsociety.org/issues/responses. php/8874

\section{Acknowledgments:}

This research was funded by the Dutch National Research Programme Knowledge for Climate (www. knowledgeforclimate.nl) and the FP7 Programma STAR-FLOOD (www.starflood.eu) under Grant Agreement No 308364.

\section{LITERATURE CITED}

Adger, W. N. 2003. Social capital, collective action, and adaptation to climate change. Economic Geography 79 (4):387-404. http://dx.doi.org/10.1111/j.1944-8287.2003.tb00220. $\underline{\mathrm{X}}$

Adger, W. N., T. Quinn, I. Lorenzoni, C. Murphy, and J. Sweeney. 2013. Changing social contracts in climate-change adaptation. Nature Climate Change 3(4):330-333. http://dx.doi.org/10.1038/ nclimate 1751

Bayertz, K. 1999. Four uses of "solidarity." Pages 3-28 in K. Bayertz, editor. Solidarity. Kluwer, Dordrecht, The Netherlands. http://dx.doi.org/10.1007/978-94-015-9245-1_1

Bernauer, T., and P. Moser. 1996. Reducing pollution of the River Rhine: the influence of international cooperation. Journal of Environment and Development 5:389-415. http://dx.doi. org/10.1177/107049659600500402
Berrang-Ford, L., J. D. Ford, and J. Paterson. 2011. Are we adapting to a changing climate? Global Environmental Change 21 (1):25-33. http://dx.doi.org/10.1016/j.gloenvcha.2010.09.012

Biesbroek, G. R., R. J. Swart, T. R. Carter, C. Cowan, T. Henrichs, H. Mela, M. D. Morecroft, and D. Rey. 2010. Europe adapts to climate change: comparing national adaptation strategies. Global Environmental Change 20(3):440-450. http://dx.doi.org/10.1016/ j.gloenvcha.2010.03.005

Boezeman, D. 2015. Transforming adaptation. Authoritative knowledge for climate change governance [in Dutch]. Dissertation. Radboud University, Nijmegen, The Netherlands. [online] URL: http://repository.ubn.ru.nl/handle/2066/141636

Boezeman, D., M. Vink, and P. Leroy. 2013 The Dutch Delta Committee as a boundary organisation. Environmental Science and Policy 27:162-171. http://dx.doi.org/10.1016/j.envsci.2012.12.016

Boezeman, D., M. Vink, P. Leroy, and W. Halffman. 2014. Participation under a spell of instrumentalization? Reflections on action research in an entrenched climate adaptation policy process. Critical Policy Studies 8(4):407-426.. http://dx.doi. org/10.1080/19460171.2014.950304

Bos, F., and P. Zwaneveld. 2012. Een snelle kosteneffectiviteitanalyse voor het Deltaprogramma IJsselmeergebied. Centraal Planbureau, The Hague, The Netherlands.

Cook, F. L. 1979. Who should be helped: public support for social services. Sage, Thousand Oaks, California, USA.

De Beer, P., and F. Koster. 2009. Sticking together or falling apart: solidarity in an age of individualization and globalization. Amsterdam University Press, Amsterdam, The Netherlands. [online] URL: https://oapen.org/download?type= document\&docid=341463 http://dx.doi.org/10.5117/9789089641281

De Boer, J., W. Botzen, and T. Terpstra. 2012. Percepties van burgers over binnen- en buitendijks wonen. Kennis voor klimaat Rapport KvK/045/2012. Rotterdam Climate Initiative, Rotterdam, The Netherlands. [online] URL: http://edepot.wur.n1/326342

Delta Commissie. 2008. Working together with water. A living land builds for its future. [in Dutch] Findings of the Delta Commissie. Delta Commissie, The Hague, The Netherlands. [online] URL: http://www.deltacommissie.com/index

Delta Programme. 2011. Delta Programme 2012. Working on the delta. Acting today, preparing for tomorrow. Delta Programme Commissioner, The Hague, The Netherlands. [online] URL: http://english.deltacommissaris.nl/delta-programme/documents/ publications/2011/09/20/deltaprogramme-2012

Delta Programme. 2013. Delta Programme 2014. Working on the delta. Promising solutions for tasking and ambitions. Delta Programme Commissioner, The Hague, The Netherlands. [online] URL: http://english.deltacommissaris.nl/delta-programme/documents/ publications/2013/09/17/delta-programme-2014

Delta Programme. 2014. Delta Programme 2015. Working on the delta. The decisions to keep the Netherlands safe and liveable. Delta Programme Commissioner, The Hague, The Netherlands. [online] URL: http://english.deltacommissaris.nl/delta-programme/documents/ publications/2014/09/16/delta-programme-2015 
Dekker, G., and H. Havekes. 2013. De financiering van het waterbeheer. Water Governance 4:15-21.

Derpmann, S. 2009. Solidarity and cosmopolitanism. Ethic Theory and Moral Practice 12(3):303-315. http://dx.doi. org/10.1007/s10677-008-9150-6

De Swaan, A. 1988. In care of the state: health care, education and welfare in Europe and the USA in the Modern Era. Bakker, Amsterdam, The Netherlands.

De Vries, A., J Veraart, I. de Vries, G. O. Essink, G. Zwolsman, R. Creusen, and H. Buijtenhek. 2009. Vraag en aanbod van zoetwater in de Zuidwestelijke Delta - een verkenning [in Dutch]. Kennis voor Klimaat Rapport 2009. Nationaal Onderzoekprogramma Kennis voor Klimaa, Utrecht, The Netherlands. [online] URL: http://edepot.wur.n1/133512

European Parliament and Council. 2007. Directive 2007/60/EC of the European Parliament and of the Council of 23 October 2007 on the assessment and management of flood risks (Floods Directive). European Parliament and Council, Brussels, Belgium. [online] URL: http://eur-lex.europa.eu/legal-content/EN/ALL/? uri=CELEX:32007L0060

Farber, D. A. 2007. Adapting to climate change: who should pay? Journal of Land Use and Environmental 23:1. http://dx.doi. org/10.2139/ssrn.980361

Flyvbjerg, B. 2006. Five misunderstandings about case-study research. Qualitative Inquiry 12(2):219-245. http://dx.doi. org/10.1177/1077800405284363

Gasper, R., A. Blohm, and M. Ruth. 2011. Social and economic aspects of climate change on the urban environment. Current Opinion in Environmental Sustainability 3(3):150-157. http://dx. doi.org/10.1016/j.cosust.2010.12.009

Government of The Netherlands, Ministry of Infrastructure and Environment (GNMIE). 2012 Water in beeld 2012: voortgangsrapportage nationaal waterplan en bestuursakkoord water over het jaar 2012 [in Dutch]. Government of The Netherlands, Ministry of Infrastructure and Environment, The Hague, The Netherlands. [online] URL: https://www. rijksoverheid.nl/documenten/kamerstukken/2013/05/14/water-inbeeld-2012

Government of The Netherlands Ministry of Transport, Public Works and Water Management (NMTPWWM). 2010. Water Act. The Netherlands Ministry of Transport, Public Works and Water Management, The Hague, The Netherlands. [online] URL: http:// www.helpdeskwater.n1/publish/pages/24783/wateract total.pdf

Helpdesk Water. 2011. Administrative agreement water. Helpdesk Water, Utrecht, the Netherlands. [online] URL: http://www. helpdeskwater.n1/onderwerpen/wetgeving-beleid/bestuursakkoord/

International Commission for Protection of the Rhine (ICPR). 1998. Action plan on floods: action targets, implementation and results 1995-2005. International Commission for Protection of the Rhine, Koblenz, Germany. [online] URL: http://www.iksr.org/ en/documentsarchive/brochures/action-plan-floods/index.html? pdfPage $=1$

Kabat, P., and H. Van Schaik. 2003. Climate changes the water rules: how water managers can cope with today's climate variability and tomorrow's climate change. Partners for Water, Delft, The Netherlands. [online] URL: http://www.hydrology.nl/images/ docs/dutch/cpwc/Climate changes water rules.pdf

Keessen, A. M., and W. W. P. Ernst. 2015. The adaptiveness of Dutch water law put to the test - dealing with water scarcity in a water-rich country. Journal of Water Law 24 (5/6):239-248.

Keessen, A. M., J. M. Hamer, H. F. M. W. Van Rijswick, and M. Wiering. 2013. The concept of resilience form a normative perspective: examples from Dutch adaptation strategies. Ecology and Society 18(2):45. http://dx.doi.org/10.5751/ES-05526-180245

Koninklijk Nederlands Meteorologisch Instituut (KNMI). 2014. KNMI'14: climate scenarios for The Netherlands. Koninklijk Nederlands Meteorologisch Instituut, Bilthoven, The Netherlands. [online] URL: http://www.climatescenarios.nl/

Komter, A. E. 2005. Social solidarity and the gift. Cambridge University Press, Cambridge, UK. http://dx.doi.org/10.1017/ cbo9780511614064

McNall, S. G. 2011. Rapid climate change: causes, consequences, and solutions. Routledge, New York, New York, USA.

Mees, H. L. P. 2016. Local governments in the driving seat? A comparative analysis of public and private responsibilities for adaptation to climate change in European and North-American cities. Journal of Environmental Policy and Planning :1-17 http:// dx.doi.org/10.1080/1523908x.2016.1223540

Mees, H. L. P., P. P. J. Driessen, and H. A. C. Runhaar. 2014. Legitimate adaptive flood risk governance beyond the dikes: the cases of Hamburg, Helsinki and Rotterdam. Regional Environmental Change 14:671-682. http://dx.doi.org/10.1007/ s10113-013-0527-2

Munoz-Dardé, V. 1999. Fraternity and justice. Pages 81-97 in K. Bayertz, editor. Solidarity. Kluwer, Dordrecht, The Netherlands. http://dx.doi.org/10.1007/978-94-015-9245-1_5

Prak, M., and J.L. Zanden. 2013. Nederland en het poldermodel: sociaal-economische geschiedenis van Nederland, 1000-2000. Bakker, Amsterdam, The Netherlands.

Steinvorth, U. 1999. The concept and possibilities of solidarity. Pages 29-38 in K. Bayertz, editor. Solidarity. Kluwer, Dordrecht, The Netherlands. http://dx.doi.org/10.1007/978-94-015-9245-1 2

Te Linde, A. H. 2011. Rhine at risk? Impact of climate change on low-probability floods in the Rhine basin and the effectiveness of flood management measure. Dissertation. VU University Amsterdam, Amsterdam, The Netherlands.

Termeer, C., A. Dewulf, H. Van Rijswick, A. van Buuren, D. Huitema, S. Meijerink, T. Rayner, and M. Wiering. 2011. The regional governance of climate adaptation: a framework for developing legitimate, effective, and resilient governance arrangements. Climate Law 2:159-179. http://dx.doi.org/10.3233/ CL-2011-032

Van Buuren, A., M. Vink, and J. Warner. 2014. Constructing authoritative answers to a latent crisis? Strategies of puzzling, powering and framing in Dutch climate adaptation practices compared. Journal of Comparative Policy Analysis: Research and Practice 18:70-87. http://dx.doi.org/10.1080/13876988.2013.877675 
van den Hurk, B., E. van Meijgaard, P. de Valk, K.-J. van Heeringen, and J. Gooijer. 2015. Analysis of a compounding surge and precipitation event in the Netherlands. Environmental Research Letters 10(3). http://dx.doi.org/10.1088/1748-9326/10/3/035001

Van Eerd, M. C. J., C. Dieperink, and M. A. Wiering. 2015b. 'A dive into floods': exploring the Dutch implementation of the floods directive. Water Policy 17(2):187-207. http://dx.doi. org/10.2166/wp.2014.025

Van Eerd, M. C. J., M. A. Wiering, and C. Dieperink. $2015 a$. Solidarity in transboundary flood risk management: a view from the Dutch North Rhine-Westphalian catchment area. Climate Policy:1-19. http://dx.doi.org/10.1080/14693062.2015.1075376

Van Houwelingen, P., A. Boele, and P. Dekker. 2014. Burgermacht op eigen kracht? Een brede verkenning van ontwikkelingen in burgerparticipatie. Sociaal en Cultureel Planbureau, Den Haag, The Netherlands. [online] URL: https://www.scp.nl/Publicaties/ Alle publicaties/Publicaties 2014/Burgermacht op eigen kracht

Van Koningsveld, M., J. P. M. Mulder, M. J. F. Stive, L. Van Der Valk, and A. W. Van Der Weck. 2008. Living with sea-level rise and climate change: a case study of the Netherlands. Journal of Coastal Research 24(2):367-379. http://dx.doi.org/10.2112/07A-0010.1

Van Oorschot, W. 2000. Who should get what, and why? On deservingness criteria and the conditionality of solidarity among the public. Policy and Politics (28)1:33-48. http://dx.doi. org/10.1332/0305573002500811

Vink, M. J., D. Benson, D. Boezeman, H. E. Cook, A. Dewulf, and C. Termeer. 2015. Do state traditions matter? Comparing deliberative governance of adaptation to climate change in Dutch corporatism and British pluralism. Journal of Water and Climate Change 6(1):71-88. http://dx.doi.org/10.2166/wcc.2014.119

Vink, M. J., D. Boezeman, A. Dewulf, and C. J. A. M. Termeer. 2013. Changing climate, changing frames: Dutch water policy frame developments in the context of a rise and fall of attention to climate change. Environmental Science and Policy 30:90-101. http://dx.doi.org/10.1016/j.envsci.2012.10.010

Vink, M. J., D. Boezeman, A. Dewulf, and C. J. A. M. Termeer. 2015. Action research in governance landscapes: partnering with city guides and gatekeepers. Pages 35-54 in A. Van Buuren, J. Eshuis, and M. Van Vliet, editors. Action research for climate change adaptation: developing and applying knowledge for governance. Routledge, London, UK.

Warner, J., P. Wester, M. J. Vink, and A. Dewulf. 2015. The politics of framing scales, ambiguity and uncertainty: flood interventions in the Netherlands. Pages 79-90 in E. S. Norman, C. Cook, and A. Cohen, editors. Negotiating water governance: why the politics of scale matter. Ashgate, London, UK.

Waterschap Scheldestromen. 2013a. Ontwerp-retributieverordening zoetwatervoorziening Tholen en Sint Philipsland. Waterschap Scheldestromen, Middelburg, The Netherlands. http://www. scheldestromen.n1/het waterschap/projecten/projecten water/tholen

Waterschap Scheldestromen. 2013b. Waterschap en ZLTO tekenen voor zoet water in Tholen en Sint Philipsland. Waterschap Scheldestromen, Middelburg, The Netherlands. http://www. scheldestromen.n1/het_waterschap/projecten/projecten_water/tholen
Waterschap Zeeuwse Eilanden (WZE). 2009. Waterbeheerplan 2010-2015: met het water mee 2. Waterschap Zeeuwse Eilanden, Middelburg, The Netherlands. https://www.zeeland.nl/digitaalarchief/ zee1000316

Wiering, M., C. Green, M. van Rijswick, S. Priest, and A. Keessen. 2015. The rationales of resilience in English and Dutch flood risk policies. Journal of Water and Climate Change 6(1):38-54. http:// dx.doi.org/10.2166/wcc. 2014.017 